\title{
RESTRUCTURING SIMULATION OF THE VENTILATION NETWORK
}

\author{
Eva BIRO', Sorin Mihai RADU ${ }^{2 *}$, Doru CIOCLEA ${ }^{3}$. Ion GHERGHE \\ ${ }^{1}$ INCD INSEMEX Petroșani, Romania \\ ${ }^{2}$ University of Petroșani, Romania, sorinradu @ upet.ro \\ ${ }^{3}$ INCD INSEMEX Petroșani, Romania \\ ${ }^{4}$ INCD INSEMEX Petroșani, Romania
}

DOI: $10.2478 / \operatorname{minrv}-2021-0029$

Keywords: simulation, ventilation, coal extraction, mining, restructuring

Abstract: Worldwide, the demand for raw materials and materials is constantly increasing, being proportional to the growth of the population. In this sense, the demand and production of solid fuels such as coal has grown steadily. At the level of the European Union, due to the restrictive coal extraction policy, production has steadily decreased and coal-producing countries have had to implement closure programs with strict deadlines. As mining networks shrink, there is an intensification of risk factors due to changes in the ventilation system. The paper presents the restructuring of a complex ventilation network.

\section{Introduction}

The exploitation of superior coals underground implies the successive execution of a complex of mining works for opening, preparation and exploitation [1,2]. As the operation expands both horizontally and vertically, some mining works are closed and others are carried out in such a way that they can put major problems in terms of ventilation. Complex ventilation networks involve the presence of parallel, diagonal and complex diagonal connections that can generate relatively low total aerodynamic resistance. Given that it is necessary to restrict the ventilation network, the number of parallel connections is reduced proportionally, which inevitably leads to the appearance of high total aerodynamic resistances. This aspect put special problems for ventilation specialists because main ventilation stations, horizons or operating blocks can be removed from the ventilation network. [3, 4, 5, 6, 7].

\section{Reason for restructuring the ventilation network}

The analyzed network is that of the Livezeni Mine which is extended horizontally [8]. In this sense there are two distinct areas connected by the directional coal and sterile galleries. The two distinct areas are:

- The western area located around layer 13 and which is opened by skip and auxiliary wells. The ventilation network in this area is sectorized and in this sense this area has the East ventilation Shaft which has to the surface the main ventilation Station East Shaft;

- The eastern area located around layer 3 and which is opened by the auxiliary shaft no. 3 of fresh air inlet. The ventilation network in this area is sectorized and in this sense this area has the ventilation shaft no. 2 which has to the surface the main ventilation Station ventilation shaft nr. 2;

The ventilation network also includes underground mining located on four horizons (horizon 100; horizon 300; horizon 350; and horizon 475). These works consist of main transverse galleries, directional galleries, diagonal galleries, transverse number galleries, inclined planes, work fronts, connecting risings.

Due to economic constraints as well as for security reasons, the decision to restrict the ventilation network can be taken. Given the difficulties of continuing to operate Layer 3, due to the spontaneous combustion phenomena that led to the closure of production capacity, the decision could be taken to continue operating

\footnotetext{
* Corresponding author: Radu Sorin Mihai, prof. Ph.D. eng., University of Petrosani, Petrosani, Romania, (University of Petrosani, 20 University Street, sorin_mihai_radu@yahoo.com)
} 
Layer 13. In this regard, the entire eastern area could be closed and the main ventilation station Auxiliary shaft no. 2, can to be stopped.

In this new situation the structure of the ventilation network can be simulated on the ventilation network modeled and solved in the current conditions $[9,10,11,12,13]$.

The specialized program used for the expected simulation is VENTSIM Visual Advanced [14].

\section{Presentation of the VENTSIM program}

Ventsim Visual Advanced is a specialized program and a very good tool for analyzing the solution and simulation of complex ventilation networks [14].

This program allows both the modeling, solving and simulation of a ventilation network and its analysis in order to optimize it. The program itself provides both information on network-specific aerodynamic parameters and information on ventilation costs.

\section{Simulation of the ventilation system of Livezeni Mine}

The simulation of the mine ventilation network was performed on the ventilation network modeled and solved in the current conditions fig. 1, [15, 16, 17, 18, 19, 20, 21].

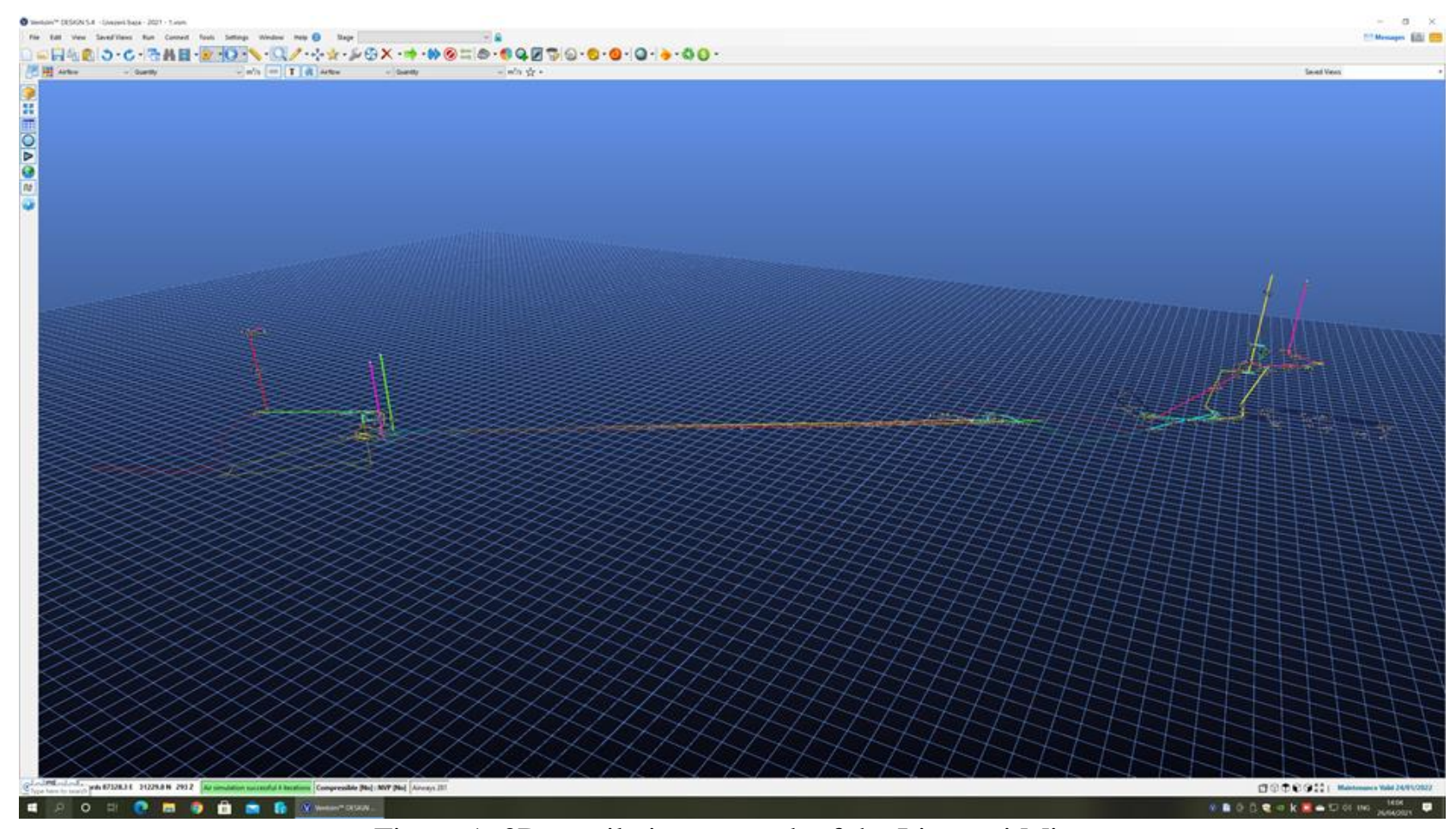

Figure 1. 3D ventilation network of the Livezeni Mine

The simulation of the restructuring of the Livezeni mine ventilation network required the elimination of the following mining works:- Coal main gallery, horizon 300;

- Sterile main gallery, horizon 300 ;

- The connection galleries of the main galleries;

- Panel 4N, horizon 300;

- Transport incline plan Panel 5N;

- Connection rising to the transport incline plan;

- Silo no. 2;

- Inclined plane for conveyor belts;

- Silo access incline plan no. 8;

- Silo no. 8;

- Silo no. 9;

- Connection gallery to Silo no. 9;

- 4N panel ventilation plan;
- Conection gallery to incline plan for conveyor belts;

- Incline plan for conveyor belts;

- Stanca ventilation incline plan;

- Ventilation rising Panel 6;

- Connection incline plan Silo no. 15;

- Silo no. 15;

- Transformation station no. 102;

- Valache ventilation incline plan;

- Transversal gallery horizon 350;

- Auxiliary shaft Circuit no. 3, horizon 350;

- Degertu rising; 
- Access gallery to Degeratu rising;

- Transversal gallery horizon 475;

- Auxiliary shaft Circuit no. 3, horizon 475;

- Auxiliary shaft no. 3;

- Delta horizon 475;

\section{pp. 1-6}

- Directional gallery horizon 475;

- Transformation station horizon 475;

- Ventilation circuit shaft no. 2 horizon 475 ,

- Ventilation shaft no. 2;

- Ventilation channel shaft no. 2;

Figure 2 shows the simulation of the ventilation network under the conditions of restructuring in the western area.

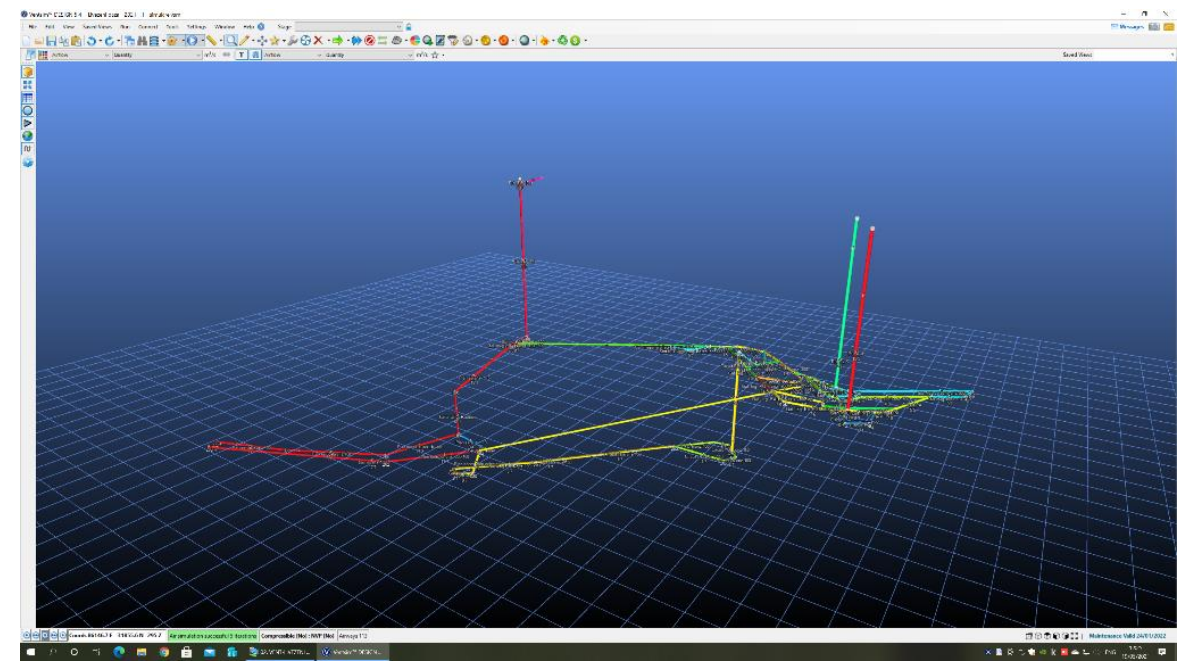

Figure 2. Simulated ventilation network after restructuring

As a result of the restructuring of the ventilation network, a number of 84 junctions and 112 connections remained.

Figures 3. - 12. show details of the ventilation network as follows: the central area Auxiliary Well - Skip shaft; Auxiliary shaft - Skip Circuit area; Detail area Puț Orb no. 6, 300-100; Detail of the Inclined Plan area, 300-100; Detail Circuit Blind shaft no. 6, horizon 100; area layer 13 oriz. 100; Detail of Hausser's rising; East Ventilation shaft Area; Detail Main ventilation station East shaft.

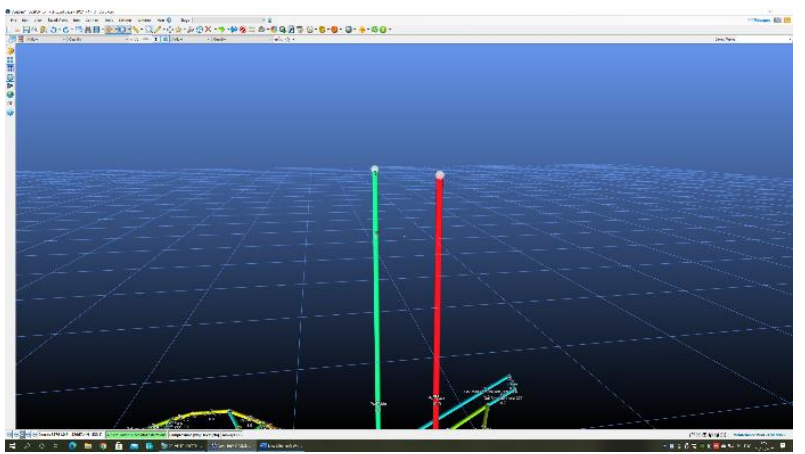

Figure 3. Skip and auxiliary well area

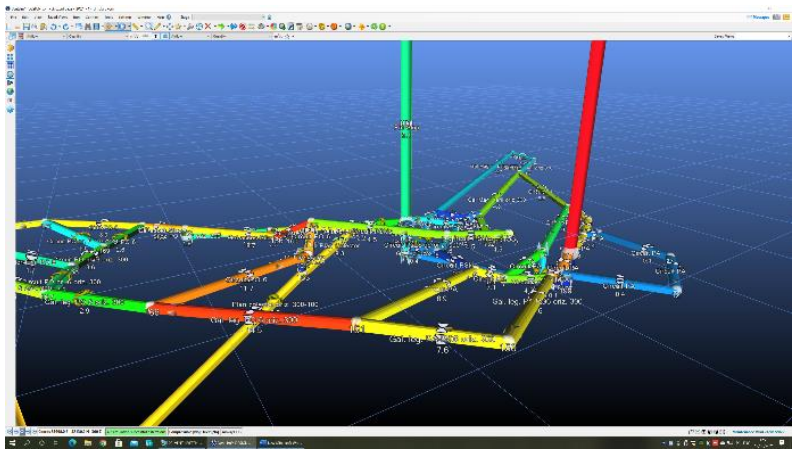

Figure 5. Auxiliary Well - Skip Well circuit area

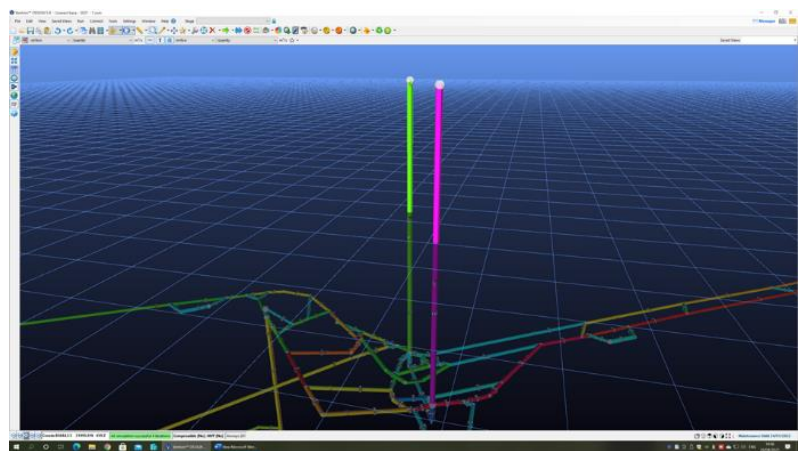

Figure 4. Central area horizon 300

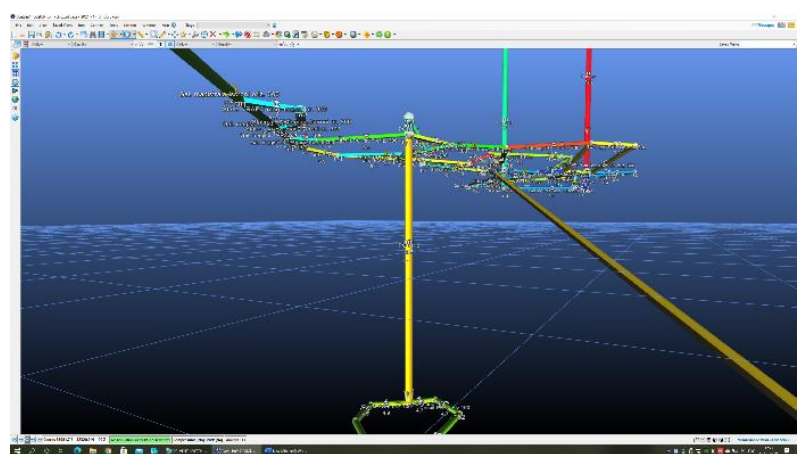

Figure 6. Blind Well no. 6, 300-100 


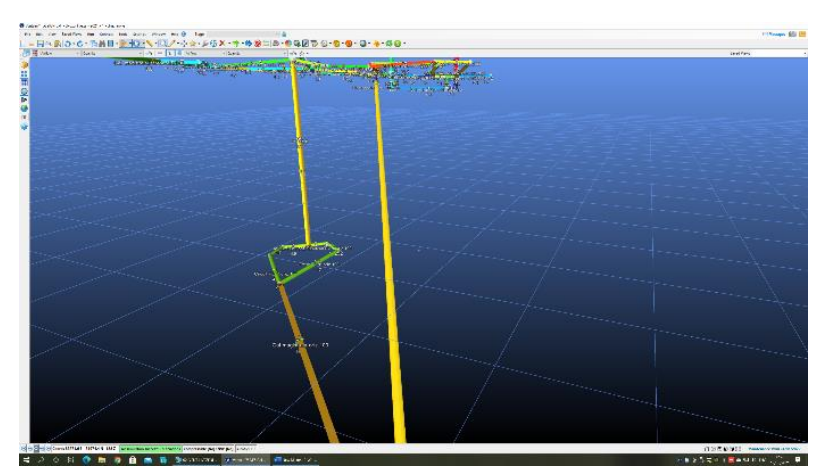

Figure 7. Inclined plane 300-100

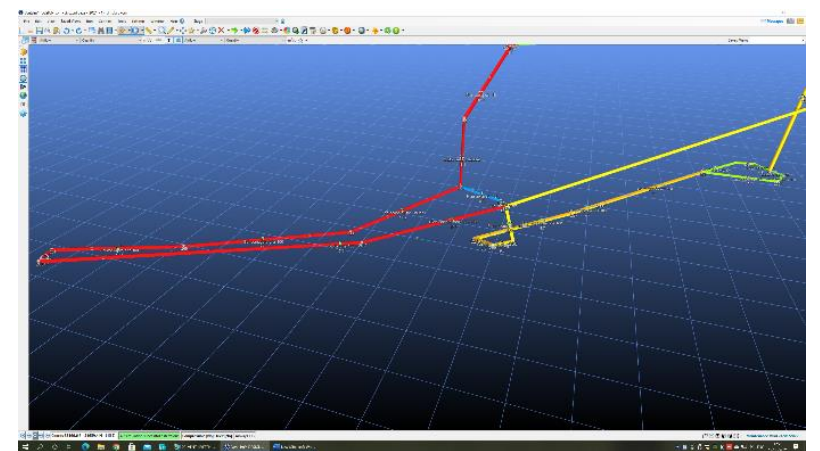

Figure 9. Layer 13 area, horizon 100

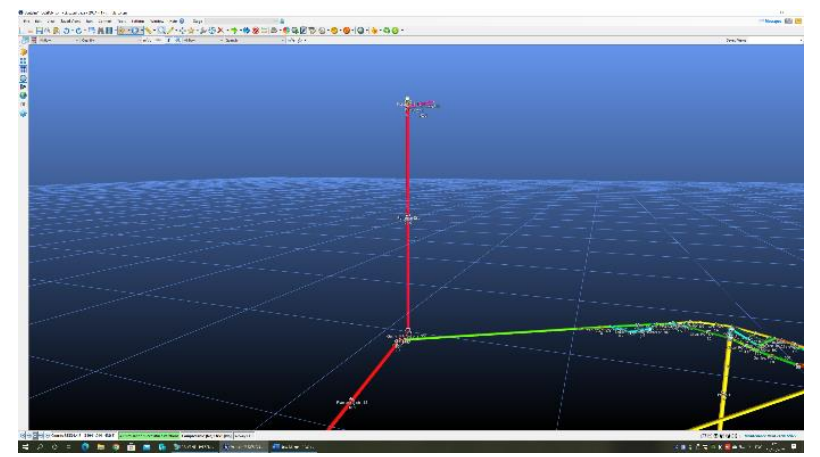

Figure 11. East Ventilation Well Area

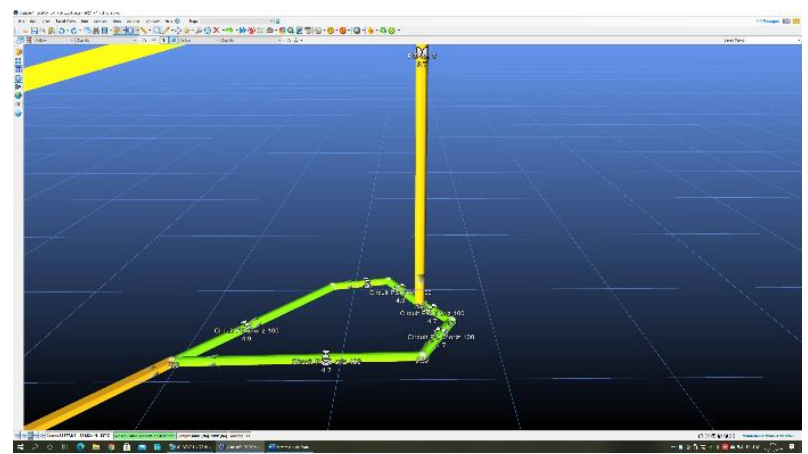

Figure 8. Blind Well no. 6 Circuit, horizon 100

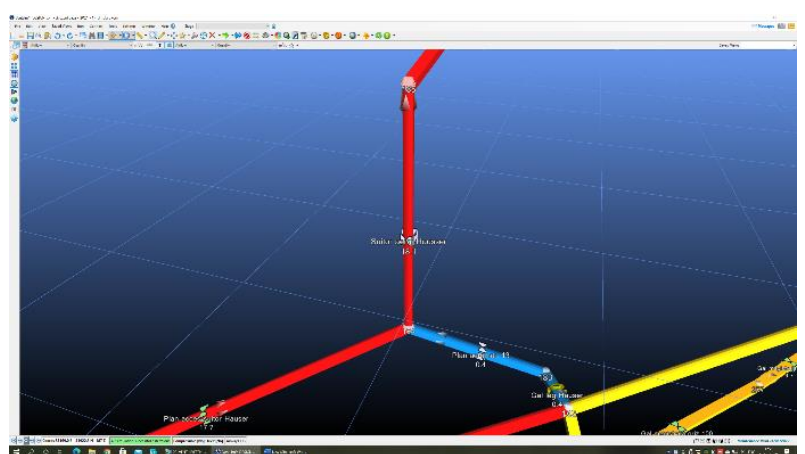

Figure 10. Hausser rising

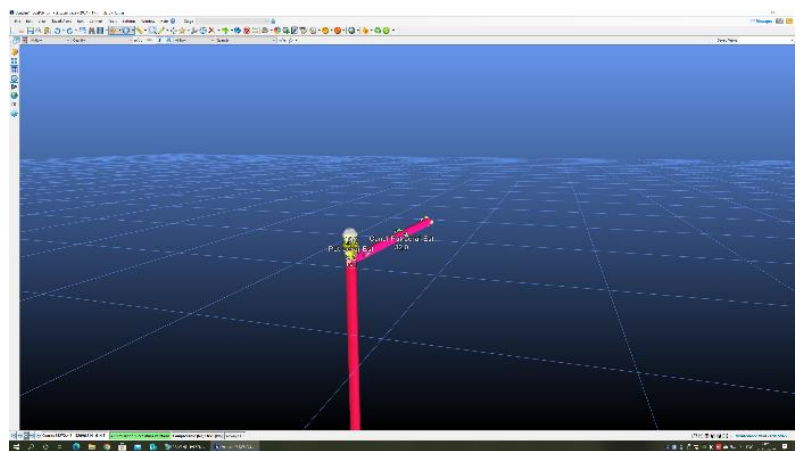

Figure 12. East Main ventilation Station

The results obtained following the simulation and solving of the ventilation network related to the restructured Livezeni mine, are presented in figure 13 for the topographic coordinates respectively in figure 14 for aerodynamic parameters.

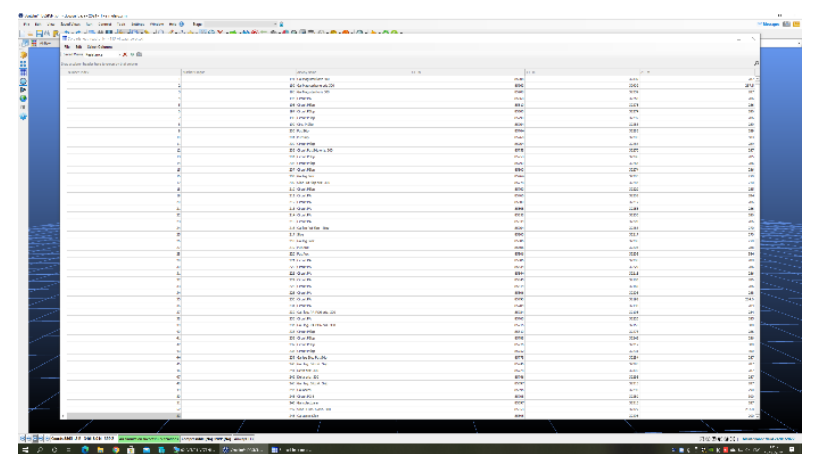

Figure 13 Topographic coordinates

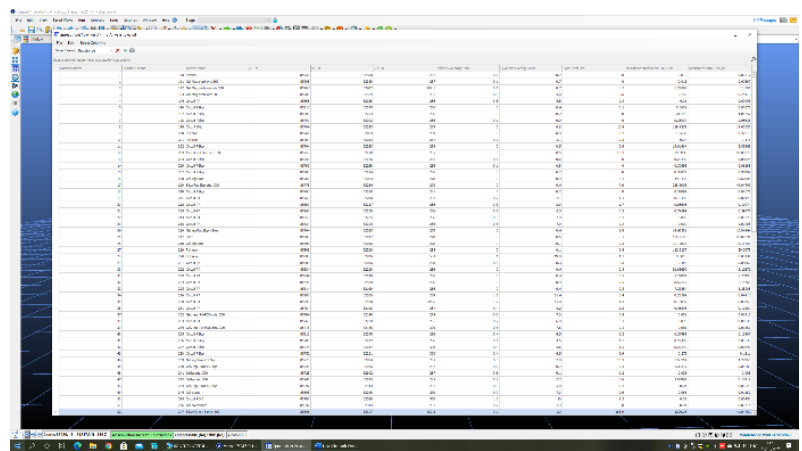

Figure 14 Aerodynamic parameters

In order to solve the ventilation network in the conditions of restriction and limitation to the western area, the following have been eliminated:

- 4 ventilation doors in the circuit area Skip shaft - Auxiliary shaft, horizon 300;

- 4 ventilation doors from the Blind shaft no. 6 area, horizon 300: 
The aerodynamic resistance on the following mining works has also been modified:

- Inclined plane collector horizon 300-100;

- Iscroni directional Gallery, horizon 300.

Following the solution of the simulated ventilation network, the following data resulted:

- A fresh air flow of $23.8 \mathrm{~m}^{3} / \mathrm{s}$ or $1428 \mathrm{~m}^{3} / \mathrm{min}$ was introduced underground, distributed as follows:

- Auxiliary shaft: $16.8 \mathrm{~m}^{3} / \mathrm{s}$ or $1008 \mathrm{~m}^{3} / \mathrm{min}$;

- Skip shaft: $7.0 \mathrm{~m}^{3} / \mathrm{s}$ or $420 \mathrm{~m}^{3} / \mathrm{min}$;

TOTAL ENTRY: $23.8 \mathrm{~m}^{3} / \mathrm{s}$ or $1428 \mathrm{~m}^{3} / \mathrm{min}$.

- $6.1 \mathrm{~m}^{3} / \mathrm{s}$ or $366 \mathrm{~m}^{3} / \mathrm{min}$ were obtained on the Iscroni main gallery;

- The air flow at the level of the blind shaft no. 6 was $10.1 \mathrm{~m}^{3} / \mathrm{s}$ or $606 \mathrm{~m}^{3} / \mathrm{min}$;

- At the level of the main gallery oriz. 100 was obtained $10.1 \mathrm{~m}^{3} / \mathrm{s}$ or $606 \mathrm{~m}^{3} / \mathrm{min}$;

- At the level of the 300-100 collector inclined plane, $7.7 \mathrm{~m}^{3} / \mathrm{s}$ or $462 \mathrm{~m}^{3} / \mathrm{min}$ was obtained;

- On the conjugated directional galleries west, horizon $100,14.4 \mathrm{~m}^{3} / \mathrm{s}$ or $864 \mathrm{~m}^{3} / \mathrm{min}$ was obtained;

- On the inclined plane of ventilation no. 15 was obtained $17.8 \mathrm{~m}^{3} / \mathrm{s}$ or $1068 \mathrm{~m}^{3} / \mathrm{min}$;

- On the East Ventilation Well, from the underground was evacuated at mine level, a defective air flow of $23.8 \mathrm{~m}^{3} / \mathrm{s}$ or $1428 \mathrm{~m}^{3} / \mathrm{min}$;

- $32 \mathrm{~m}^{3} / \mathrm{s}$ or $1920 \mathrm{~m}^{3} / \mathrm{min}$ were evacuated at the level of the East Main Ventilation Station;

- The short-cut air flow with the surface was $8.2 \mathrm{~m}^{3} / \mathrm{s}$ or $492 \mathrm{~m}^{3} / \mathrm{min}$.

\section{Conclusions}

The specialized program Ventsim Visual Advanced was used to simulate the ventilation network, under restructuring conditions, of the Livezeni mine.

As a result of performing the simulation in solid 3D system, a number of 84 junctions and 112 connections resulted.

Ventsim Visual Advanced is a specialized program and a very good tool for analyzing the solution and simulation of complex ventilation networks

To simulate the ventilation network of the Livezeni mine, 34 ventilation circuits or mining works were eliminated. Also, 8 ventilation doors were eliminated and at the level of 2 other ventilation doors the aerodynamic resistances were modified.

From the underground, the air flow at the mine level of $23.8 \mathrm{~m} 3 / \mathrm{s}$ or $1428 \mathrm{~m} 3 / \mathrm{min}$ was evacuated from the underground;

At the level of the main fan, $32.0 \mathrm{~m} 3 / \mathrm{s}$ or $1920 \mathrm{~m} 3 / \mathrm{min}$. was evacuated.

The short-cut air flow with the surface was $8.2 \mathrm{~m} 3 / \mathrm{s}$ or $492 \mathrm{~m} 3 / \mathrm{min}$.

\section{References}

[1] Almăşan B., 1984

The exploitation of mineral deposits in România (in Romanian), Technical Publishing București

[2] Covaci Ş., 1983

Underground mining (in Romanian), Didactic and Pedagogic Publishing București

[3] Băltăreţu R., Teodorescu C., 1971

Mining ventilation and work protection (in Romanian), Didactic and Pedagogic Publishing București

[4] Matei I., Moraru R, e.a., 2000

Environmental engineering and underground ventilation Technical Publishing București

[5] Patterson A.M., 1992

The Mine Ventilation Practitioner's Data Book, M.V.S. of South Africa

[6] Todorescu C., Gontean Z., Neag I., 1971

Mining ventilation (in Romanian), Technical Publishing București

$[7] * *, 1990$

Le Roux - Notes on Mine environmental control, M.V.S. of South Africa 
$[8] * * *, 2021$

Technical documentation, Livezeni Mining Unit

[9] Boantă C., 2019

The management of the ventilation complex network of Vulcan Mine from the Valea Jiului mining area and the establishment of gas dynamics (in Romanian), Doctoral thesis, University of Petrosani

[10] Chiuzan E., 2019

The management of the ventilation network from Praid Salt Mine (in Romanian), Doctoral thesis, University of Petrosani

[11] Morar M.S., 2016

Research on the improvement of the ventilation networks management from the mining exploitations in Valea Jiului (in Romanian), Doctoral thesis, University of Petrosani

[12] Rădoi F., 2018

The optimization of ventilation networks from the Valea Jiului's closing mines, for the increase of work safety (in Romanian), Doctoral thesis, University of Petrosani

[13] Șuvar M., 2017

Research on the restauration of the mining ventilation networks after explosions (in Romanian), Doctoral thesis, University of Petrosani

[14]***, 2010

VENTSIM Visual Advanced - User's Guide

[15] Cioclea D., 2006

Solving the ventilation network problems on depressiometric measurements in order to establish the air flows, depressions and aerodynamic resistances on works from E.M. Paroșeni (in Romanian), INSEMEX research.

[16] Cioclea D., 2007-2009

Reducing the risks generated by explosives by using the real-time evaluation technique of the ventilation networks for human protection (in Romanian), INSEMEX research.

[17] Cioclea D., 2010-2011

Reducing the explosion danger for the black coal mines in Valea Jiului through the computer management of the ventilation networks (in Romanian), INSEMEX research.

[18] Gherghe I., 1998

Determining the characteristic curves of the main ventilation fans from E.M. Livezeni (in Romanian), INSEMEX research.

[19] Ianc N., 2018

Curved determinations characteristic for the main ventilation installations Puț Aeraj 2 and Puț Aeraj East-E.M. Livezeni (in Romanian), INSEMEX research.

[20] Matei A., 2014

The determination of the characteristic curves of fans and of the functional parameters from the main ventilation stations - Puț East and Puț Aeraj 2 from E.M. Livezeni (in Romanian), INSEMEX research.

[21] Rădoi F., 2015

The determination of characteristic curves of the fans and of the functional parameters from the main ventilation installation Puț Aeraj 2, on the inclination angle value of the rotor blades of $\alpha=15^{\circ}$, from E.M. Livezeni, (in Romanian), INSEMEX research. 